\title{
What Do We Know about Antimicrobial Activity of Astaxanthin and Fucoxanthin?
}

\author{
Tomasz M. Karpiński ${ }^{1, *(\mathbb{D})}$, Marcin Ożarowski ${ }^{2} \mathbb{D}$, Rahat Alam ${ }^{3,4} \mathbb{( D}$, Małgorzata Lochyńska $^{2} \mathbb{D}$ \\ and Mark Stasiewicz ${ }^{5}$ (D)
}

1 Chair and Department of Medical Microbiology, Poznań University of Medical Sciences, Wieniawskiego 3, 61-712 Poznań, Poland

2 Department of Biotechnology, Institute of Natural Fibres and Medicinal Plants, Wojska Polskiego 71b, 60-630 Poznań, Poland; marcin.ozarowski@iwnirz.pl (M.O.); malgorzata.lochynska@iwnirz.pl (M.Ł.)

3 Department of Genetic Engineering and Biotechnology, Faculty of Biological Science and Technology, Jashore University of Science and Technology, Jashore 7408, Bangladesh; rahat_160619@just.edu.bd

4 Biological Solution Centre (BioSol Centre), Farmgate, Dhaka 1215, Bangladesh

5 Research Group of Medical Microbiology, Chair and Department of Medical Microbiology, Poznań University of Medical Sciences, Wieniawskiego 3, 61-712 Poznań, Poland; 84682@student.ump.edu.pl

* Correspondence: tkarpin@ump.edu.pl; Tel.: +48-61-854-61-38

Citation: Karpiński, T.M.; Ożarowski, M.; Alam, R.;

Łochyńska, M.; Stasiewicz, M. What Do We Know about Antimicrobial

Activity of Astaxanthin and

Fucoxanthin?. Mar. Drugs 2022, 20, 36 https://doi.org/10.3390/md20010036

Academic Editors: Jean-Luc Mouget and Laurent Picot

Received: 6 December 2021

Accepted: 28 December 2021

Published: 29 December 2021

Publisher's Note: MDPI stays neutral with regard to jurisdictional claims in published maps and institutional affiliations.

Copyright: () 2021 by the authors Licensee MDPI, Basel, Switzerland. This article is an open access article distributed under the terms and conditions of the Creative Commons Attribution (CC BY) license (https:// creativecommons.org/licenses/by/ $4.0 /)$.

\begin{abstract}
Astaxanthin (AST) and fucoxanthin (FUC) are natural xanthophylls, having multidirectional activity, including antioxidant, anti-inflammatory, and anticancer. Both compounds also show antimicrobial activity, which is presented in this review article. There are few papers that have presented the antimicrobial activity of AST. Obtained antimicrobial concentrations of AST (200-4000 $\mu \mathrm{g} / \mathrm{mL}$ ) are much higher than recommended by the European Food Safety Authority for consumption ( $2 \mathrm{mg}$ daily). Therefore, we suggest that AST is unlikely to be of use in the clinical treatment of infections. Our knowledge about the antimicrobial activity of FUC is better and this compound acts against many bacteria already in low concentrations $10-250 \mu \mathrm{g} / \mathrm{mL}$. Toxicological studies on animals present the safety of FUC application in doses $200 \mathrm{mg} / \mathrm{kg}$ body weight and higher. Taking available research into consideration, a clinical application of FUC as the antimicrobial substance is real and can be successful. However, this aspect requires further investigation. In this review, we also present potential mechanisms of antibacterial activity of carotenoids, to which AST and FUC belong.
\end{abstract}

Keywords: mechanisms of action; efflux pump; biofilm inhibition; toxicity; safety; carcinogenicity

\section{Introduction}

Astaxanthin (AST) and fucoxanthin (FUC) are natural xanthophyll pigments belonging to carotenoids [1]. AST was first isolated from lobster by Kuhn and Sorensen in 1938 [2]. The AST is 3,3'-dihydroxy- $\beta, \beta$-carotene- $4,4^{\prime}$-dione (Figure 1 ), and its molecular formula is $\mathrm{C}_{40} \mathrm{H}_{52} \mathrm{O}_{4}$ [3]. It was demonstrated that AST is produced by some microorganisms, including bacteria (e.g., Escherichia coli, Mycobacterium lacticola, Paracoccus carotinifaciens, and Brevibacterium sp.), green microalgae (e.g., Haematococcus pluvialis, Chlorella zofingiensis, and Chlamydomonas nivalis) and yeasts (e.g., Phaffia rhodozyma = Xanthophyllomyces dendrorhous, and Rhodosporidium toruloides) [4-6].

FUC was first isolated from the seaweeds Fucus, Dictyota, and Laminaria by Willstätter and Page in 1914 [7]. The FUC is $3^{\prime}$-acetoxy-5,6-epoxy-3, $5^{\prime}$-dihydroxy-6 $6^{\prime}, 7^{\prime}$-didehydro-5,6,7,8, $5^{\prime}, 6^{\prime}$ hexahydro- $\beta$, $\beta$-carotene-8-one (Figure 1), and its molecular formula is $\mathrm{C}_{42} \mathrm{H}_{58} \mathrm{O}_{6}$ [8]. FUC is present in brown seaweeds belonging among others to the genera Dictyota, Ecklonia, Fucus, Hijikia, Laminaria, Petalonia, Sargassum, Scytosiphon, Sphaerotrichia, and Undaria [7-12]. 
<smiles>CC1=C(/C=C/C=C/C(C)=C/C=C/C=C(C)/C=C/C=C(C)/C=C/C2=C(C)C(=O)[C@@H](O)CC2(C)C)C(C)(C)C[C@H](O)C1=O</smiles>

Astaxanthin<smiles>CC(=O)O[C@@H]1CC(C)(C)C(=C=C=C(C)C=CC=C(C)C=CC=CC=C(C)C=CC=C(C)C(=O)C[C@@]23O[C@@]2(C)C[C@@H](O)CC3(C)C)[C@](C)(O)C1</smiles>

Fucoxanthin

Figure 1. Chemical structures of AST and FUC.

Many studies showed that AST and FUC have antioxidant [12-16], antiinflammatory [14,17-20], and anticancer [21-25] activities. It was also demonstrated that these phycochemical constituents have anti-diabetic [26,27], anti-obesity [28-30], and neuroprotective effects [31-33]. Both compounds also contain antimicrobial activity, and this aspect is presented in the review.

Therefore, the aim of this review is to show the recent data concerning the antibacterial, antifungal, antiviral, and antiparasitic activity of AST and FUC. The PubMed, Medline, and Scopus databases were used to search for articles using the keywords "astaxanthin", "fucoxanthin", "antibacterial", "antifungal", "antiviral", "antiparasitic", "activity", and "effect". Additionally, a manual review of references from the obtained literature was performed. Papers in which applied doses/concentrations of AST or FUC were missing were excluded from this review.

\section{Astaxanthin}

There is a small number of studies presenting the antimicrobial activity of AST. Shanmugapriya et al. [34] demonstrated that AST in the form of nanoemulsion can act against various bacteria. MIC values for Gram-positive and Gram-negative species were $500-4000 \mu \mathrm{g} / \mathrm{mL}$ [34]. In the in vitro study of Trypanosoma cruzi, the viability of the parasite was decreased in doses of AST 200-300 $\mu \mathrm{g} / \mathrm{mL}$. Simultaneously, the authors did not observe the therapeutic effect of AST against acute T. cruzi infection in the mice model [35]. In animal studies of mice infected with Helicobacter pylori, it was shown that AST has an impact on the decrease of bacterial abundance in the stomach. AST also had an anti-inflammatory effect reducing gastric inflammation and cytokine production by splenocytes [36]. In addition, some studies have shown a significant decrease of gastric $H$. pylori colonization in mice treated with an algal meal rich in AST [37]. In in silico studies, it was demonstrated that some xanthophylls, including AST, can inhibit SARS-CoV-2, acting on viral papain-like protease [38].

Recently, recommended or approved doses of AST in different countries amount to between 2 and $24 \mathrm{mg}$. According to the European Food Safety Authority, the proposed acceptable daily intake of AST is $2 \mathrm{mg}$ [39]. AST is approved by the United States Food and Drug Administration (FDA) as generally recognized as safe (GRAS) for animals and humans for use in food $[40,41]$. It is important that according to the EU Regulation (EC) No. 1925/2006, the synthetic AST is not allowed for use in food, and that it has no GRAS status in the US [3,42]. Spiller and Dewell demonstrated that AST is safe in a dosage of $6 \mathrm{mg} /$ day [40]. The EFSA Panel on Dietetic Products, Nutrition, and Allergies recommended that the daily dose of AST should not exceed $4 \mathrm{mg}(0.06 \mathrm{mg} / \mathrm{kg} \mathrm{bw} /$ day for a 
70-kg person) [43]. Many studies have demonstrated that AST is also safe in much higher doses, up to $40 \mathrm{mg}$, without developing side effects [44-46]. Simultaneously, other papers demonstrated the following side effects: an increased frequency in bowel movement [47], stomach/abdominal pain [48], itch, dyspepsia, muscle pain, or diarrhea [49]. In animal studies, AST in repeat-doses of 100, 250, or $500 \mathrm{mg} / \mathrm{kg}$ bw showed no organ, hematological and biochemical abnormalities in pregnant mice [50]. In research with the use of Ames and in vitro micronucleus tests, a lack of AST genotoxicity has been shown. In the same paper, in a 2-year-long study on mice, the authors did not show the carcinogenicity potential of AST. However, in rats carcinogenicity of AST was observed in doses of 200 and $1000 \mathrm{mg} / \mathrm{kg}$ bw/day. Hepatocellular adenoma was developed in $18 \%$ of rats fed with $200 \mathrm{mg}$ AST $/ \mathrm{kg}$ bw/day and in $28 \%$ of animals fed with $1000 \mathrm{mg} / \mathrm{kg}$ bw/day [41].

The antimicrobial concentrations of AST, presented in Table 1, are much higher than recommended for consumption. This means that despite being active in high concentrations, AST is unlikely to be of clinical use in the treatment of infections or as an additional antimicrobial compound.

Table 1. Antimicrobial activity of astaxanthin.

\begin{tabular}{cc}
\hline Targeted Microorganism & Antimicrobial Doses \\
\hline Bacillus subtilis & in vitro, nanoemulsion, MIC 500-4000 $\mathrm{mg} / \mathrm{mL}$ \\
Escherichia coli & in vitro, nanoemulsion, MIC 500-4000 $\mu \mathrm{g} / \mathrm{mL}$ \\
Helicobacter pylori & in vivo, mice, 200 mg per kg body weight per day \\
Pseudomonas aeruginosa & in vitro, nanoemulsion, MIC 500-4000 $\mu \mathrm{gg} / \mathrm{mL}$ \\
Staphylococcus aureus & in vitro, nanoemulsion, MIC 1000-2000 $\mu \mathrm{gg} / \mathrm{mL}$ \\
Streptococcus mutans & in vitro, nanoemulsion, MIC 500-2000 $\mu \mathrm{gg} / \mathrm{mL}$ \\
SARS-CoV-2 & [34] \\
Trypanosoma cruzi & in vitro, 200-300 $\mu \mathrm{mg} / \mathrm{mL}$; lack of in vivo activity \\
\hline
\end{tabular}

\section{Fucoxanthin}

Our knowledge about the antimicrobial activity of FUC is better than that of AST. In in vitro studies, FUC often acts against aerobic bacteria in low concentrations $10-250 \mu \mathrm{g} / \mathrm{mL}$ but has poor activity against anaerobic bacteria with MICs $>1000 \mu \mathrm{g} / \mathrm{mL}[8,51]$. In the big study, including 20 bacterial species, FUC acted against 13 aerobic bacteria. Obtained MICs for Gram-positive bacteria were between 62.5 and $250 \mu \mathrm{g} / \mathrm{mL}$ (median $125 \mu \mathrm{g} / \mathrm{mL}$ ), while for Gram-negative ones were from 125 to $500 \mu \mathrm{g} / \mathrm{mL}$ (median $250 \mu \mathrm{g} / \mathrm{mL}$ ) [8]. In another study including three Gram-positive and three Gram-negative bacteria, FUC extracted from Turbinaria triquetra had better activity, already in concentrations from 10-100 $\mu \mathrm{g} / \mathrm{mL}$ [51]. Interestingly, very low MIC values were demonstrated against Mycobacterium tuberculosis: these were 2.8-4.1 $\mu \mathrm{M}(1.85-2.7 \mu \mathrm{g} / \mathrm{mL})$ [52]. In a much higher concentration of $1000 \mu \mathrm{g} / \mathrm{mL}$, FUC also acts against Listeria monocytogenes [53]. According to our previous studies, in the case of natural compounds, including flavonoids, organic acids, and curcumin, values of MIC above $1000 \mu \mathrm{g} / \mathrm{mL}$ should be considered as poor activity or lack of activity [54-56]. So high concentrations have no real therapeutic application and should be marked as inactive against microorganisms. A very high concentration of FUC, amounting to $4250 \mu \mathrm{g} / \mathrm{mL}$, was used in the study of Liu et al. [57] against S. aureus, Enterococcus sp., B. subtilis, and P. aeruginosa. In another work by Peraman and Nachimuthu [58], MIC values of FUC were obtained against bacteria and also fungi (Aspergillus brasiliensis, A. fumigatus and Candida albicans), and amounted to $1000-4000 \mu \mathrm{g} / \mathrm{mL}$.

In animal studies with chickens, it was observed that diet supplemented with $100 \mathrm{mg} / \mathrm{kg}$ or $200 \mathrm{mg} / \mathrm{kg}$ FUC meaningfully reduced the amount of Enterobacteriaceae, total mesophilic aerobic bacteria (TMAB), Staphylococcus spp., and Pseudomonas spp. from one to six days, in comparison to standard feed, without FUC. It is very interesting that FUC had low or no effect on the count of probiotic bacteria Lactobacillus spp. [59].

There are also individual studies concerning antiviral and antiparasitic effects of FUC. FUC from a brown alga Dictyota sp. acted against Herpes simplex virus type 1 
and Plasmodium falciparum [60]. The activity of FUC against Plasmodium falciparum was also shown on a Chinese hamster ovarian cell line, with simultaneously relatively low cytotoxicity on the cell line [61].

There are no recommendations of acceptable daily intake of FUC; however, as shown by some studies, FUC is already active in low concentrations of $10-250 \mu \mathrm{g} / \mathrm{mL}$.

Toxicological studies on rats demonstrated that a 28-day repeated oral dosing of fucoxanthin (95\% purity) on rats in doses of 10 and $50 \mathrm{mg} / \mathrm{kg} /$ day did not show toxicity [62]. By contrast, oil containing FUC was safe in a dose of $200 \mathrm{mg} / \mathrm{kg}$ body weight in rats over a period of 13 weeks of feeding. Doses higher than $2000 \mathrm{mg} / \mathrm{kg}$ body weight led to $50 \%$ mortality [63]. Another study on mice confirmed the safety of single orally administered doses of 1000 and $2000 \mathrm{mg} / \mathrm{kg}$ and repeated doses of 500 and $1000 \mathrm{mg} / \mathrm{kg}$ administered for 30 days. In the study, no mortality or abnormalities were observed [64]. Both above studies indicate that FUC has a high level of safety. This means that a clinical application of FUC is more likely to be successful than AST, in addition to its use as an antimicrobial substance.

The antimicrobial activity of FUC is presented in Table 2.

Table 2. Antimicrobial activity of fucoxanthin.

\begin{tabular}{|c|c|c|}
\hline Targeted Microorganism & Antimicrobial Doses & References \\
\hline Acinetobacter lwoffii & in vitro, MIC $250 \mu \mathrm{g} / \mathrm{mL}$ & [8] \\
\hline Actinomyces israelii & in vitro, MIC > $1000 \mu \mathrm{g} / \mathrm{mL}$ & [8] \\
\hline Atopobium parvulum & in vitro, MIC > $1000 \mu \mathrm{g} / \mathrm{mL}$ & [8] \\
\hline Bacillus cereus & in vitro, $10-100 \mu \mathrm{g} / \mathrm{mL}$ & [51] \\
\hline \multirow{3}{*}{ Bacillus subtilis } & in vitro, $10-100 \mu \mathrm{g} / \mathrm{mL}$ & [51] \\
\hline & in vitro, MIC $4000 \mu \mathrm{g} / \mathrm{mL}$ & [58] \\
\hline & in vitro, $4250 \mu \mathrm{g} / \mathrm{mL}$ & [57] \\
\hline Enterobacteriaceae & in vivo, chicken, $100-200 \mathrm{mg} / \mathrm{kg}$ & [59] \\
\hline Enterococcus sp. & in vitro, $4250 \mu \mathrm{g} / \mathrm{mL}$ & [57] \\
\hline \multirow{2}{*}{ Enterococcus faecalis } & in vitro, MIC $125-250 \mu \mathrm{g} / \mathrm{mL}$ & [8] \\
\hline & in vitro, $4250 \mu \mathrm{g} / \mathrm{mL}$ & [57] \\
\hline \multirow{3}{*}{ Escherichia coli } & in vitro, $10-100 \mu \mathrm{g} / \mathrm{mL}$ & {$[51]$} \\
\hline & in vitro, MIC $125 \mu \mathrm{g} / \mathrm{mL}$ & [8] \\
\hline & in vitro, MIC $2000 \mu \mathrm{g} / \mathrm{mL}$ & [58] \\
\hline Klebsiella oxytoca & in vitro, MIC $125-250 \mu \mathrm{g} / \mathrm{mL}$ & [8] \\
\hline \multirow{3}{*}{ Klebsiella pneumoniae } & in vitro, $10-100 \mu \mathrm{g} / \mathrm{mL}$ & {$[51]$} \\
\hline & in vitro, MIC $250 \mu \mathrm{g} / \mathrm{mL}$ & [8] \\
\hline & in vitro, MIC $1000 \mu \mathrm{g} / \mathrm{mL}$ & [58] \\
\hline Listeria monocytogenes & in vitro, $1000 \mu \mathrm{g} / \mathrm{mL}$ & [53] \\
\hline Mitsuokella multacida & in vitro, $\mathrm{MIC}>1000 \mu \mathrm{g} / \mathrm{mL}$ & [8] \\
\hline Mycobacterium tuberculosis & in vitro, MIC $1.85-2.7 \mu \mathrm{g} / \mathrm{mL}$ & [52] \\
\hline Peptococcus niger & in vitro, $\mathrm{MIC}>1000 \mu \mathrm{g} / \mathrm{mL}$ & [8] \\
\hline Porphyromonas gingivalis & in vitro, MIC > $1000 \mu \mathrm{g} / \mathrm{mL}$ & [8] \\
\hline Propionibacterium acnes & in vitro, MIC > $1000 \mu \mathrm{g} / \mathrm{mL}$ & [8] \\
\hline Proteus mirabilis & in vitro, MIC $500 \mu \mathrm{g} / \mathrm{mL}$ & [8] \\
\hline Pseudomonas spp. & in vivo, chicken, $100-200 \mathrm{mg} / \mathrm{kg}$ & [59] \\
\hline
\end{tabular}


Table 2. Cont.

\begin{tabular}{|c|c|c|}
\hline Targeted Microorganism & Antimicrobial Doses & References \\
\hline \multirow{4}{*}{ Pseudomonas aeruginosa } & in vitro, $10-100 \mu \mathrm{g} / \mathrm{mL}$ & [51] \\
\hline & in vitro, MIC $250-500 \mu \mathrm{g} / \mathrm{mL}$ & {$[8]$} \\
\hline & in vitro, MIC $1000 \mu \mathrm{g} / \mathrm{mL}$ & [58] \\
\hline & in vitro, $4250 \mu \mathrm{g} / \mathrm{mL}$ & [57] \\
\hline Staphylococcus spp. & in vivo, chicken, $100-200 \mathrm{mg} / \mathrm{kg}$ & {$[59]$} \\
\hline \multirow{4}{*}{ Staphylococcus aureus } & in vitro, $10-100 \mu \mathrm{g} / \mathrm{mL}$ & [51] \\
\hline & in vitro, MIC $125 \mu \mathrm{g} / \mathrm{mL}$ & [8] \\
\hline & in vitro, MIC $1000 \mu \mathrm{g} / \mathrm{mL}$ & [58] \\
\hline & in vitro, $4250 \mu \mathrm{g} / \mathrm{mL}$ & [57] \\
\hline Staphylococcus epidermidis & in vitro, MIC $125 \mu \mathrm{g} / \mathrm{mL}$ & [8] \\
\hline Streptococcus agalactiae & in vitro, MIC $62.5 \mu \mathrm{g} / \mathrm{mL}$ & [8] \\
\hline Streptococcus pneumoniae & in vitro, MIC $125 \mu \mathrm{g} / \mathrm{mL}$ & [8] \\
\hline Streptococcus pyogenes & in vitro, MIC $125 \mu \mathrm{g} / \mathrm{mL}$ & {$[8]$} \\
\hline Serratia marcescens & in vitro, MIC $500 \mu \mathrm{g} / \mathrm{mL}$ & [8] \\
\hline Veilonella parvula & in vitro, $\mathrm{MIC}>1000 \mu \mathrm{g} / \mathrm{mL}$ & [8] \\
\hline Total mesophilic aerobic bacteria (TMAB) & in vivo, chicken, $100-200 \mathrm{mg} / \mathrm{kg}$ & [59] \\
\hline Aspergillus brasiliensis & in vitro, MIC $2000 \mu \mathrm{g} / \mathrm{mL}$ & [58] \\
\hline Aspergillus fumigatus & in vitro, MIC $1000 \mu \mathrm{g} / \mathrm{mL}$ & [58] \\
\hline Candida albicans & in vitro, MIC $2000 \mu \mathrm{g} / \mathrm{mL}$ & [58] \\
\hline Herpes simplex virus type 1 & in vitro, IC50 $5 \mu \mathrm{g} / \mathrm{mL}$ & {$[60]$} \\
\hline \multirow{2}{*}{ Plasmodium falciparum } & in vitro, EC50 $2.9 \mu \mathrm{g} / \mathrm{mL}$ & {$[60]$} \\
\hline & in vitro, IC50 $1.3 \mu \mathrm{g} / \mathrm{mL}(1.5 \mu \mathrm{M})$ & [61] \\
\hline
\end{tabular}

\section{Potential Mechanisms of Antibacterial Action of AST and FUC}

The mechanisms of the antimicrobial activity of xanthophylls are little known. However, it is very likely that potential mechanisms of action of xanthophylls are the same or similar to the mechanisms described in the carotenoids and terpenoids class, to which xanthophylls belong. It was recently discovered that small terpenoids, like carvacrol, can act directly on bacterial cell and membrane, leading to damage of the cell wall and membrane and leakage of cell content [65]. Terpenoids have also the ability to permeabilize and depolarize the cytoplasmic membrane [43]. It was also observed that FUC can increase cell membrane permeability and thus the leakage of cytoplasm [66]. AST and FUC are compounds, having 40 and 42 carbon atoms, respectively. Therefore, xanthophylls are more similar to antibiotic molecules, like macrolides, which also have about 40 carbon atoms. This suggests that their remaining mechanisms of action may require a link to a protein receptor or nucleic acid. Some data from the literature indicate that terpenoids, including carotenoids, can modulate efflux pumps [67-69]. The exact mechanism was described among others in alkaloids and flavonoids [70,71]. Moreover, terpenoids can lead to the accumulation of toxic compounds inside bacteria and can have an impact on ATP hydrolysis, leading to disturbance of efflux pump activation. In Gram-negative bacteria, these compounds can increase the permeability of the outer membrane and can change the conformation of efflux protein structures $[67,68]$. Terpenoids can also lead to the accumulation of intracellular reactive oxygen species (ROS), which can damage the bacterial cells, causing oxidative damage of membranes, DNA, proteins, and lipid peroxidation [72-74]. Another mechanism of action of terpenoids, including carotenoids and xanthophylls, is the 
inhibition of biofilm formation, both in bacteria and fungi. This effect can be triggered by inhibition of biofilm matrix formation, decreasing cell adhesion, inhibition of the virulence factors, e.g., toxin production, and blocking the quorum sensing network [75-77]. Action through inhibition of bacterial virulence and blocking of quorum sensing and biofilm was described in flavonoids [70]. Anti-quorum and anti-biofilm activities were also demonstrated for two xanthophylls: lutein and zeaxanthin [78,79]. Some studies confirmed that FUC can affect lipopolysaccharide (LPS), an endotoxin of Gram-negative bacteria, which impacts inflammatory response. FUC can suppress the NF- $\mathrm{KB}$ activation and inhibit the production of pro-inflammatory cytokines induced by LPS [80-82]. It was also suggested that FUC can act antibacterial by nucleic acid inhibition [66]. Mahizan et al. [67] proposed two more mechanisms: inhibition of oxygen uptake and alteration in oxidative phosphorylation. Terpenoids act mainly against aerobic bacteria, for which oxidative phosphorylation is a key biochemical process responsible for cellular respiration. The action of terpenoids leads to a reduction in oxygen concentration, disturbance of bacterial respiration, and ultimately death of the bacteria $[83,84]$. Potential antibacterial mechanisms of carotenoids, such as AST and FUC, are presented in Figure 2.

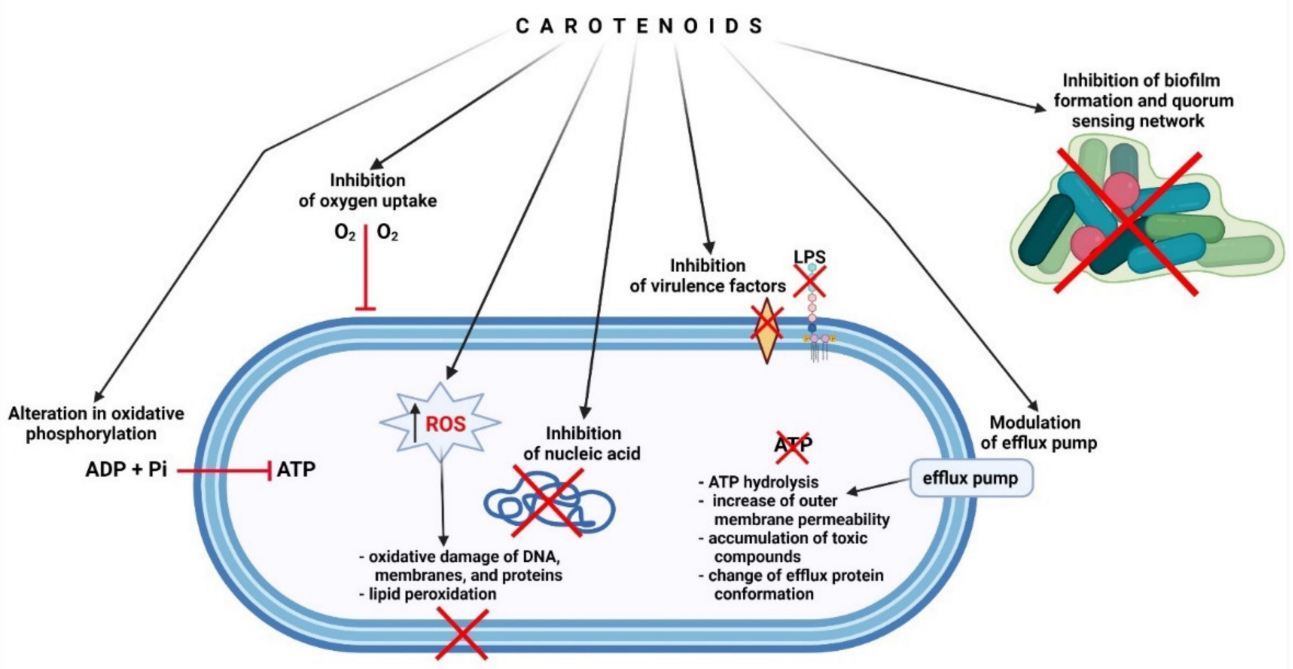

Figure 2. Potential antibacterial mechanisms of action of carotenoids, such as astaxanthin and fucoxanthin.

\section{Conclusions}

As demonstrated in the literature, antimicrobial concentrations of astaxanthin are much higher than recommended by the European Food Safety for consumption. Therefore, this compound is unlikely to be of clinical use in the treatment of infections. In the case of fucoxanthin, it acts against many bacteria in low concentrations. Simultaneously, toxicological studies present the safety of fucoxanthin application in high doses. Therefore, a clinical application of fucoxanthin as an antimicrobial substance is real and can be successful. However, this aspect requires further research.

Author Contributions: Conceptualization, T.M.K. and M.O.; methodology, T.M.K. and M.O.; resources, T.M.K., M.O., R.A., M.Ł. and M.S.; writing-original draft preparation, T.M.K. and M.O.; writing-review and editing, R.A., M.Ł. and M.S.; visualization, T.M.K.; supervision, T.M.K. All authors have read and agreed to the published version of the manuscript.

Funding: This research received no external funding.

Institutional Review Board Statement: Not applicable.

Conflicts of Interest: The authors declare no conflict of interest. 


\section{References}

1. Pereira, A.G.; Otero, P.; Echave, J.; Carreira-Casais, A.; Chamorro, F.; Collazo, N.; Jaboui, A.; Lourenço-Lopes, C.; Simal-Gandara, J.; Prieto, M.A. Xanthophylls from the Sea: Algae as Source of Bioactive Carotenoids. Mar. Drugs 2021, 19, 188. [CrossRef] [PubMed]

2. Kuhn, R.; Sörensen, N.A. Über Astaxanthin und Ovoverdin. Berichte Dtsch. Chem. Ges. A B Ser. 1938, 71, 1879-1888. [CrossRef]

3. Stachowiak, B.; Szulc, P. Astaxanthin for the Food Industry. Molecules 2021, 26, 2666. [CrossRef]

4. Tran, T.N.; Tran, Q.-V.; Huynh, H.T.; Hoang, N.-S.; Nguyen, H.C.; Ngo, D.-N. Astaxanthin Production by Newly Isolated Rhodosporidium toruloides: Optimization of Medium Compositions by Response Surface Methodology. Not. Bot. Horti Agrobot. Cluj-Napoca 2018, 47, 320-327. [CrossRef]

5. Villaró, S.; Ciardi, M.; Morillas-España, A.; Sánchez-Zurano, A.; Acién-Fernández, G.; Lafarga, T. Microalgae Derived Astaxanthin: Research and Consumer Trends and Industrial Use as Food. Foods 2021, 10, 2303. [CrossRef] [PubMed]

6. Ambati, R.R.; Phang, S.-M.; Ravi, S.; Aswathanarayana, R.G. Astaxanthin: Sources, Extraction, Stability, Biological Activities and Its Commercial Applications-A Review. Mar. Drugs 2014, 12, 128-152. [CrossRef] [PubMed]

7. Peng, J.; Yuan, J.-P.; Wu, C.-F.; Wang, J.-H. Fucoxanthin, a Marine Carotenoid Present in Brown Seaweeds and Diatoms: Metabolism and Bioactivities Relevant to Human Health. Mar. Drugs 2011, 9, 1806-1828. [CrossRef] [PubMed]

8. Karpiński, T.M.; Adamczak, A. Fucoxanthin-An Antibacterial Carotenoid. Antioxidants 2019, 8, 239. [CrossRef]

9. Mori, K.; Ooi, T.; Hiraoka, M.; Oka, N.; Hamada, H.; Tamura, M.; Kusumi, T. Fucoxanthin and Its Metabolites in Edible Brown Algae Cultivated in Deep Seawater. Mar. Drugs 2004, 2, 63-72. [CrossRef]

10. D'Orazio, N.; Gemello, E.; Gammone, M.A.; de Girolamo, M.; Ficoneri, C.; Riccioni, G. Fucoxantin: A Treasure from the Sea. Mar. Drugs 2012, 10, 604-616. [CrossRef]

11. Jung, H.A.; Ali, M.Y.; Choi, R.J.; Jeong, H.O.; Chung, H.Y.; Choi, J.S. Kinetics and molecular docking studies of fucosterol and fucoxanthin, BACE1 inhibitors from brown algae Undaria pinnatifida and Ecklonia stolonifera. Food Chem. Toxicol. 2016, 89, 104-111. [CrossRef]

12. Maeda, H.; Fukuda, S.; Izumi, H.; Saga, N. Anti-Oxidant and Fucoxanthin Contents of Brown Alga Ishimozuku (Sphaerotrichia divaricata) from the West Coast of Aomori, Japan. Mar. Drugs 2018, 16, 255. [CrossRef] [PubMed]

13. Yi, B.; Kim, M.-J.; Lee, J. Antioxidant Properties of Astaxanthin in Oil-in-Water Emulsions with Differently-Charged Emulsifiers Under Chlorophyll Photosensitization. J. Food Sci. 2018, 83, 589-596. [CrossRef] [PubMed]

14. Takatani, N.; Kono, Y.; Beppu, F.; Okamatsu-Ogura, Y.; Yamano, Y.; Miyashita, K.; Hosokawa, M. Fucoxanthin inhibits hepatic oxidative stress, inflammation, and fibrosis in diet-induced nonalcoholic steatohepatitis model mice. Biochem. Biophys. Res. Commun. 2020, 528, 305-310. [CrossRef] [PubMed]

15. Gao, S.; Heng, N.; Liu, F.; Guo, Y.; Chen, Y.; Wang, L.; Ni, H.; Sheng, X.; Wang, X.; Xing, K.; et al. Natural astaxanthin enhanced antioxidant capacity and improved semen quality through the MAPK/Nrf2 pathway in aging layer breeder roosters. J. Anim. Sci. Biotechnol. 2021, 12, 112. [CrossRef]

16. Kumar, S.; Kumar, R.; Diksha; Kumari, A.; Panwar, A. Astaxantzithin: A super antioxidant from microalgae and its therapeutic potential. J. Basic Microbiol. 2021. [CrossRef] [PubMed]

17. Chang, M.X.; Xiong, F. Astaxanthin and its Effects in Inflammatory Responses and Inflammation-Associated Diseases: Recent Advances and Future Directions. Molecules 2020, 25, 5342. [CrossRef] [PubMed]

18. Kim, M.-B.; Kang, H.; Li, Y.; Park, Y.-K.; Lee, J.-Y. Fucoxanthin inhibits lipopolysaccharide-induced inflammation and oxidative stress by activating nuclear factor E2-related factor 2 via the phosphatidylinositol 3-kinase/AKT pathway in macrophages. Eur. J. Nutr. 2021, 60, 3315-3324. [CrossRef]

19. Kohandel, Z.; Farkhondeh, T.; Aschner, M.; Pourbagher-Shahri, A.M.; Samarghandian, S. Anti-inflammatory action of astaxanthin and its use in the treatment of various diseases. Biomed. Pharmacother. 2021, 145, 112179. [CrossRef]

20. Masoudi, A.; Jorjani, M.; Alizadeh, M.; Mirzamohammadi, S.; Mohammadi, M. Anti-inflammatory and antioxidant effects of astaxanthin following spinal cord injury in a rat animal model. Brain Res. Bull. 2021, 177, 324-331. [CrossRef] [PubMed]

21. Kim, K.-N.; Heo, S.-J.; Kang, S.-M.; Ahn, G.; Jeon, Y.-J. Fucoxanthin induces apoptosis in human leukemia HL-60 cells through a ROS-mediated Bcl-xL pathway. Toxicol. Vitr. 2010, 24, 1648-1654. [CrossRef] [PubMed]

22. Faraone, I.; Sinisgalli, C.; Ostuni, A.; Armentano, M.F.; Carmosino, M.; Milella, L.; Russo, D.; Labanca, F.; Khan, H. Astaxanthin anticancer effects are mediated through multiple molecular mechanisms: A systematic review. Pharmacol. Res. 2020, 155, 104689. [CrossRef] [PubMed]

23. Lee, H.; Lim, J.W.; Kim, H. Effect of Astaxanthin on Activation of Autophagy and Inhibition of Apoptosis in Helicobacter pylori-Infected Gastric Epithelial Cell Line AGS. Nutrients 2020, 12, 1750. [CrossRef] [PubMed]

24. Sun, S.-Q.; Zhao, Y.-X.; Li, S.-Y.; Qiang, J.-W.; Ji, Y.-Z. Anti-Tumor Effects of Astaxanthin by Inhibition of the Expression of STAT3 in Prostate Cancer. Mar. Drugs 2020, 18, 415. [CrossRef] [PubMed]

25. Terasaki, M.; Kubota, A.; Kojima, H.; Maeda, H.; Miyashita, K.; Kawagoe, C.; Mutoh, M.; Tanaka, T. Fucoxanthin and Colorectal Cancer Prevention. Cancers 2021, 13, 2379. [CrossRef] [PubMed]

26. Zhuge, F.; Ni, Y.; Wan, C.; Liu, F.; Fu, Z. Anti-diabetic effects of astaxanthin on an STZ-induced diabetic model in rats. Endocr. J. 2021, 68, 451-459. [CrossRef]

27. Maeda, H. Nutraceutical Effects of Fucoxanthin for Obesity and Diabetes Therapy: A Review. J. Oleo Sci. 2015, 64, 125-132. [CrossRef] 
28. Maeda, H.; Kanno, S.; Kodate, M.; Hosokawa, M.; Miyashita, K. Fucoxanthinol, Metabolite of Fucoxanthin, Improves ObesityInduced Inflammation in Adipocyte Cells. Mar. Drugs 2015, 13, 4799-4813. [CrossRef]

29. Gammone, M.A.; D'Orazio, N. Anti-Obesity Activity of the Marine Carotenoid Fucoxanthin. Mar. Drugs 2015, 13, 2196-2214. [CrossRef]

30. Wang, M.; Ma, H.; Guan, S.; Luo, T.; Zhao, C.; Cai, G.; Zheng, Y.; Jia, X.; Di, J.; Li, R.; et al. Astaxanthin from Haematococcus pluvialis alleviates obesity by modulating lipid metabolism and gut microbiota in mice fed a high-fat diet. Food Funct. 2021, 12, 9719-9738. [CrossRef]

31. Zhang, L.; Wang, H.; Fan, Y.; Gao, Y.; Li, X.; Hu, Z.; Ding, K.; Wang, Y.; Wang, X. Fucoxanthin provides neuroprotection in models of traumatic brain injury via the Nrf2-ARE and Nrf2-autophagy pathways. Sci. Rep. 2017, 7, 46763. [CrossRef]

32. Kim, R.-E.; Shin, C.Y.; Han, S.-H.; Kwon, K.J. Astaxanthin Suppresses PM2.5-Induced Neuroinflammation by Regulating Akt Phosphorylation in BV-2 Microglial Cells. Int. J. Mol. Sci. 2020, 21, 7227. [CrossRef] [PubMed]

33. Gao, F.; Wu, X.; Mao, X.; Niu, F.; Zhang, B.; Dong, J.; Liu, B. Astaxanthin Provides Neuroprotection in an Experimental Model of Traumatic Brain Injury via the Nrf2/HO-1 Pathway. Am. J. Transl Res. 2021, 13, 1483-1493.

34. Shanmugapriya, K.; Kim, H.; Saravana, P.S.; Chun, B.-S.; Kang, H.W. Astaxanthin-Alpha Tocopherol Nanoemulsion Formulation by Emulsification Methods: Investigation on Anticancer, Wound Healing, and Antibacterial Effects. Colloids Surf. B Biointerfaces 2018, 172, 170-179. [CrossRef]

35. Contreras-Ortiz, J.M.E.; Barbabosa-Pliego, A.; Oros-Pantoja, R.; Aparicio-Burgos, J.E.; Zepeda-Escobar, J.A.; Hassan-Moustafa, W.H.; Ochoa-García, L.; Alonso-Fresan, M.U.; Borroto, E.T.; Vázquez-Chagoyán, J.C. Effects of astaxanthin in mice acutely infected with Trypanosoma cruzi. Parasite 2017, 24, 17. [CrossRef] [PubMed]

36. Bennedsen, M.; Wang, X.; Willén, R.; Wadström, T.; Andersen, L.P. Treatment of H. pylori infected mice with antioxidant astaxanthin reduces gastric inflammation, bacterial load and modulates cytokine release by splenocytes. Immunol. Lett. 2000, 70, 185-189. [CrossRef]

37. Wang, X.; Willén, R.; Wadström, T. Astaxanthin-Rich Algal Meal and Vitamin C Inhibit Helicobacter pylori Infection in BALB/cA Mice. Antimicrob. Agents Chemother. 2000, 44, 2452-2457. [CrossRef]

38. Karpiński, T.M.; Kwaśniewski, M.; Ożarowski, M.; Alam, R. In silico studies of selected xanthophylls as potential candidates against SARS-CoV-2 targeting main protease (Mpro) and papain-like protease (PLpro). Herba Pol. 2021, 67, 1-8. [CrossRef]

39. Brendler, T.; Williamson, E.M. Astaxanthin: How much is too much? A safety review. Phytotherapy Res. 2019, $33,3090-3111$. [CrossRef]

40. Spiller, G.A.; Dewell, A. Safety of an Astaxanthin-Rich Haematococcus pluvialis Algal Extract: A Randomized Clinical Trial. J. Med. Food 2003, 6, 51-56. [CrossRef]

41. Edwards, J.A.; Bellion, P.; Beilstein, P.; Rümbeli, R.; Schierle, J. Review of genotoxicity and rat carcinogenicity investigations with astaxanthin. Regul. Toxicol. Pharmacol. 2016, 75, 5-19. [CrossRef]

42. EUR-Lex-32006R1925-EN-EUR-Lex. Available online: https:/ / eur-lex.europa.eu/eli/reg/2006/1925/oj (accessed on 21 December 2021).

43. Scientific Opinion on the Safety of Astaxanthin-Rich Ingredients (AstaREAL A1010 and AstaREAL L10) as Novel Food Ingredients I EFSA. Available online: https://www.efsa.europa.eu/en/efsajournal/pub/3757 (accessed on 21 December 2021).

44. Chalyk, N.E.; Klochkov, V.A.; Bandaletova, T.Y.; Kyle, N.H.; Petyaev, I.M. Continuous astaxanthin intake reduces oxidative stress and reverses age-related morphological changes of residual skin surface components in middle-aged volunteers. Nutr. Res. 2017, 48, 40-48. [CrossRef] [PubMed]

45. Hayashi, M.; Ishibashi, T.; Maoka, T. Effect of astaxanthin-rich extract derived from Paracoccus carotinifaciens on cognitive function in middle-aged and older individuals. J. Clin. Biochem. Nutr. 2018, 62, 195-205. [CrossRef] [PubMed]

46. Kim, J.H.; Chang, M.J.; Choi, H.D.; Youn, Y.-K.; Kim, J.T.; Oh, J.M.; Shin, W.G. Protective Effects of Haematococcus Astaxanthin on Oxidative Stress in Healthy Smokers. J. Med. Food 2011, 14, 1469-1475. [CrossRef] [PubMed]

47. Choi, H.D.; Youn, Y.K.; Shin, W.G. Positive Effects of Astaxanthin on Lipid Profiles and Oxidative Stress in Overweight Subjects. Plant. Foods Hum. Nutr. 2011, 66, 363-369. [CrossRef] [PubMed]

48. Kupcinskas, L.; Lafolie, P.; Lignell, A.; Kiudelis, G.; Jonaitis, L.; Adamonis, K.; Andersen, L.P.; Wadström, T. Efficacy of the Natural Antioxidant Astaxanthin in the Treatment of Functional Dyspepsia in Patients with or without Helicobacter Pylori Infection: A Prospective, Randomized, Double Blind, and Placebo-Controlled Study. Phytomedicine 2008, 15, 391-399. [CrossRef]

49. Trimarco, V.; Battistoni, A.; Tocci, G.; Coluccia, R.; Manzi, M.V.; Izzo, R.; Volpe, M. Single Blind, Multicentre, Randomized, Controlled Trial Testing the Effects of a Novel Nutraceutical Compound on Plasma Lipid and Cardiovascular Risk Factors: Results of the Interim Analysis. Nutr. Metab. Cardiovasc. Dis. 2017, 27, 850-857. [CrossRef] [PubMed]

50. Niu, T.; Zhou, J.; Wang, F.; Xuan, R.; Chen, J.; Wu, W.; Chen, H. Safety Assessment of Astaxanthin from Haematococcus pluvialis: Acute Toxicity, Genotoxicity, Distribution and Repeat-Dose Toxicity Studies in Gestation Mice. Regul. Toxicol. Pharm. 2020, 115, 104695. [CrossRef]

51. Deyab, M.A.; Abou-Dobara, M.I. Antibacterial activity of some marine algal extracts against most nosocomial bacterial infections. Egypt. J. Exp. Biol. Bot. 2013, 9, 281-286.

52. Šudomová, M.; Shariati, M.A.; Echeverría, J.; Berindan-Neagoe, I.; Nabavi, S.M.; Hassan, S.T.S. A Microbiological, Toxicological, and Biochemical Study of the Effects of Fucoxanthin, a Marine Carotenoid, on Mycobacterium tuberculosis and the Enzymes Implicated in Its Cell Wall: A Link Between Mycobacterial Infection and Autoimmune Diseases. Mar. Drugs 2019, $17,641$. [CrossRef] 
53. Rajauria, G.; Abu-Ghannam, N. Isolation and Partial Characterization of Bioactive Fucoxanthin from Himanthalia elongata Brown Seaweed: A TLC-Based Approach. Int. J. Anal. Chem. 2013, 2013, 802573. [CrossRef] [PubMed]

54. Adamczak, A.; Ożarowski, M.; Karpiński, T.M. Antibacterial Activity of Some Flavonoids and Organic Acids Widely Distributed in Plants. J. Clin. Med. 2019, 9, 109. [CrossRef] [PubMed]

55. Adamczak, A.; Ożarowski, M.; Karpiński, T.M. Curcumin, a Natural Antimicrobial Agent with Strain-Specific Activity. Pharmaceuticals 2020, 13, 153. [CrossRef]

56. Chanaj-Kaczmarek, J.; Osmałek, T.; Szymańska, E.; Winnicka, K.; Karpiński, T.M.; Dyba, M.; Bekalarska-Dębek, M.; Cielecka-Piontek, J. Development and Evaluation of Thermosensitive Hydrogels with Binary Mixture of Scutellariae baicalensis radix Extract and Chitosan for Periodontal Diseases Treatment. Int. J. Mol. Sci. 2021, 22, 11319. [CrossRef]

57. Liu, Z.; Sun, X.; Sun, X.; Wang, S.; Xu, Y. Fucoxanthin Isolated from Undaria pinnatifida Can Interact with Escherichia coli and lactobacilli in the Intestine and Inhibit the Growth of Pathogenic Bacteria. J. Ocean. Univ. China 2019, 18, 926-932. [CrossRef]

58. Peraman, M.; Nachimuthu, S. Identification and quantification of fucoxanthin in selected carotenoid-producing marine microalgae and evaluation for their chemotherapeutic potential. Pharmacogn. Mag. 2019, 15, 243. [CrossRef]

59. Gumus, R.; Gelen, S.U.; Koseoglu, S.; Ozkanlar, S.; Ceylan, Z.; Imik, H. The Effects of Fucoxanthin Dietary Inclusion on the Growth Performance, Antioxidant Metabolism and Meat Quality of Broilers. Braz. J. Poult. Sci. 2018, 20, 487-496. [CrossRef]

60. Jongaramruong, J.; Kongkam, N. Novel diterpenes with cytotoxic, anti-malarial and anti-tuberculosis activities from a brown alga Dictyota sp. J. Asian Nat. Prod. Res. 2007, 9, 743-751. [CrossRef] [PubMed]

61. Afolayan, A.F.; Bolton, J.J.; Lategan, C.A.; Smith, P.J.; Beukes, D.R. Fucoxanthin, Tetraprenylated Toluquinone and Toluhydroquinone Metabolites from Sargassum heterophyllum Inhibit the in vitro Growth of the Malaria Parasite Plasmodium falciparum. Z. Nat. C 2008, 63, 848-852. [CrossRef]

62. Kadekaru, T.; Toyama, H.; Yasumoto, T. Safety Evaluation of Fucoxanthin purified from Undaria pinnatifida. Nippon. Shokuhin Kagaku Kogaku Kaishi 2008, 55, 304-308. [CrossRef]

63. Iio, K.; Okada, Y.; Ishikura, M. Single and 13-Week Oral Toxicity Study of Fucoxanthin Oil from Microalgae in Rats. J. Food Hyg. Soc. Jpn. (Shokuhin Eiseigaku Zasshi) 2011, 52, 183-189. [CrossRef]

64. Beppu, F.; Niwano, Y.; Tsukui, T.; Hosokawa, M.; Miyashita, K. Single and repeated oral dose toxicity study of fucoxanthin (FX), a marine carotenoid, in mice. J. Toxicol. Sci. 2009, 34, 501-510. [CrossRef] [PubMed]

65. Gutiérrez-Del-Río, I.; Fernández, J.; Lombó, F. Plant nutraceuticals as antimicrobial agents in food preservation: Terpenoids, polyphenols and thiols. Int. J. Antimicrob. Agents 2018, 52, 309-315. [CrossRef]

66. Silva, A.; Silva, S.A.; Carpena, M.; Garcia-Oliveira, P.; Gullón, P.; Barroso, M.F.; Prieto, M.A.; Simal-Gandara, J. Macroalgae as a Source of Valuable Antimicrobial Compounds: Extraction and Applications. Antibiotics 2020, 9, E642. [CrossRef] [PubMed]

67. Mahizan, N.A.; Yang, S.-K.; Moo, C.L.; Song, A.A.-L.; Chong, C.-M.; Chong, C.-W.; Abushelaibi, A.; Lim, S.-H.E.; Lai, K.-S. Terpene Derivatives as a Potential Agent against Antimicrobial Resistance (AMR) Pathogens. Molecules 2019, 24, E2631. [CrossRef] [PubMed]

68. Seukep, A.J.; Kuete, V.; Nahar, L.; Sarker, S.D.; Guo, M. Plant-derived secondary metabolites as the main source of efflux pump inhibitors and methods for identification. J. Pharm. Anal. 2020, 10, 277-290. [CrossRef] [PubMed]

69. Jubair, N.; Rajagopal, M.; Chinnappan, S.; Abdullah, N.B.; Fatima, A. Review on the Antibacterial Mechanism of Plant-Derived Compounds against Multidrug-Resistant Bacteria (MDR). Evid. Based Complement. Altern. Med. 2021, 2021, 3663315. [CrossRef] [PubMed]

70. Górniak, I.; Bartoszewski, R.; Króliczewski, J. Comprehensive review of antimicrobial activities of plant flavonoids. Phytochem. Rev. 2019, 18, 241-272. [CrossRef]

71. Siriyong, T.; Srimanote, P.; Chusri, S.; Yingyongnarongkul, B.-E.; Suaisom, C.; Tipmanee, V.; Voravuthikunchai, S.P. Conessine as a novel inhibitor of multidrug efflux pump systems in Pseudomonas aeruginosa. BMC Complement. Altern. Med. 2017, 17, 405. [CrossRef] [PubMed]

72. Liu, J.; Zhu, Y.; Du, G.; Zhou, J.; Chen, J. Response of Saccharomyces cerevisiae to D-limonene-induced oxidative stress. Appl. Microbiol. Biotechnol. 2013, 97, 6467-6475. [CrossRef]

73. Martins, I.; Varela, A.; Frija, L.M.T.; Estevão, M.A.S.; Planchon, S.; Renaut, J.; Afonso, C.A.M.; Pereira, C.S. Proteomic Insights on the Metabolism of Penicillium janczewskii during the Biotransformation of the Plant Terpenoid Labdanolic Acid. Front. Bioeng. Biotechnol. 2017, 5, 45. [CrossRef]

74. Tziveleka, L.-A.; Tammam, M.A.; Tzakou, O.; Roussis, V.; Ioannou, E. Metabolites with Antioxidant Activity from Marine Macroalgae. Antioxidants 2021, 10, 1431. [CrossRef]

75. Raut, J.S.; Shinde, R.B.; Chauhan, N.M.; Karuppayil, S.M. Terpenoids of Plant Origin Inhibit Morphogenesis, Adhesion, and Biofilm Formation by Candida Albicans. Biofouling 2013, 29, 87-96. [CrossRef]

76. Guzzo, F.; Scognamiglio, M.; Fiorentino, A.; Buommino, E.; D'Abrosca, B. Plant Derived Natural Products against Pseudomonas aeruginosa and Staphylococcus aureus: Antibiofilm Activity and Molecular Mechanisms. Molecules 2020, 25, 5024. [CrossRef]

77. Kostoglou, D.; Protopappas, I.; Giaouris, E. Common Plant-Derived Terpenoids Present Increased Anti-Biofilm Potential against Staphylococcus Bacteria Compared to a Quaternary Ammonium Biocide. Foods 2020, 9, 697. [CrossRef] [PubMed]

78. Gökalsın, B.; Aksoydan, B.; Erman, B.; Sesal, N.C. Reducing Virulence and Biofilm of Pseudomonas aeruginosa by Potential Quorum Sensing Inhibitor Carotenoid: Zeaxanthin. Microb. Ecol. 2017, 74, 466-473. [CrossRef] [PubMed] 
79. Sampathkumar, S.J.; Srivastava, P.; Ramachandran, S.; Sivashanmugam, K.; Gothandam, K.M. Lutein: A potential antibiofilm and antiquorum sensing molecule from green microalga Chlorella pyrenoidosa. Microb. Pathog. 2019, 135, 103658. [CrossRef] [PubMed]

80. Heo, S.-J.; Yoon, W.-J.; Kim, K.-N.; Oh, C.; Choi, Y.-U.; Yoon, K.-T.; Kang, D.-H.; Qian, Z.-J.; Choi, I.-W.; Jung, W.-K. Antiinflammatory effect of fucoxanthin derivatives isolated from Sargassum siliquastrum in lipopolysaccharide-stimulated RAW 264.7 macrophage. Food Chem. Toxicol. 2012, 50, 3336-3342. [CrossRef] [PubMed]

81. Jiang, X.; Wang, G.; Lin, Q.; Tang, Z.; Yan, Q.; Yu, X. Fucoxanthin prevents lipopolysaccharide-induced depressive-like behavior in mice via AMPK- NF-кB pathway. Metab. Brain Dis. 2019, 34, 431-442. [CrossRef] [PubMed]

82. Kim, K.-N.; Heo, S.-J.; Yoon, W.-J.; Kang, S.-M.; Ahn, G.; Yi, T.-H.; Jeon, Y.-J. Fucoxanthin inhibits the inflammatory response by suppressing the activation of NF- $\mathrm{kB}$ and MAPKs in lipopolysaccharide-induced RAW 264.7 macrophages. Eur. J. Pharmacol. 2010, 649, 369-375. [CrossRef] [PubMed]

83. Zengin, H.; Baysal, A.H. Antibacterial and Antioxidant Activity of Essential Oil Terpenes against Pathogenic and SpoilageForming Bacteria and Cell Structure-Activity Relationships Evaluated by SEM Microscopy. Molecules 2014, 19, 17773-17798. [CrossRef] [PubMed]

84. Griffin, S.G.; Wyllie, S.G.; Markham, J.L.; Leach, D.N. The Role of Structure and Molecular Properties of Terpenoids in Determining Their Antimicrobial Activity. Flavour Fragr. J. 1999, 14, 322-332. [CrossRef] 